\title{
Ethnologies
}

\section{The cultural legacy of the frontier lands of Vinalopó (Alicante, Spain) and their tourist use - impossible mission?}

\section{Antonio Martínez Puche et Salvador Martínez Puche}

Volume 38, numéro 1-2, 2016

Créativité et médiation en tourisme et en patrimoine

Creativity and mediation in tourism and heritage

URI : https://id.erudit.org/iderudit/1041595ar

DOI : https://doi.org/10.7202/1041595ar

Aller au sommaire du numéro

Éditeur(s)

Association Canadienne d'Ethnologie et de Folklore

ISSN

1481-5974 (imprimé)

1708-0401 (numérique)

Découvrir la revue

Citer cet article

Martínez Puche, A. \& Martínez Puche, S. (2016). The cultural legacy of the frontier lands of Vinalopó (Alicante, Spain) and their tourist use - impossible mission? Ethnologies, 38(1-2), 237-254. https://doi.org/10.7202/1041595ar
Résumé de l'article

Le « tourisme des frontières » ou " tourisme de partage " est une véritable typologie du tourisme présentant les quatre traits suivants : l'espace (géographique), le temps (historique), l'expérience (motivations et comportements) et le partage du patrimoine culturel (matériel et immatériel). Les terres frontalières d'Alto Vinalopó (Alicante, Espagne) comportent un double élément paradoxal au sens où elles constituent un territoire aux traditions et coutumes ayant de nombreuses similitudes avec les autres, mais qui en même temps présentent un certain nombre de contrastes et de particularités.

À présent réorganisées en attractions touristiques potentielles, ces démonstrations ethnographiques aux racines profondes deviennent des produits de consommation qui s'efforcent de se trouver une position différentielle sur le marché des loisirs.

Cet article se donne pour objectif d'illustrer ce processus en analysant ses variables socioculturelles, économiques et promotionnelles au moyen de l'examen d'un événement particulier : les Fêtes des Maures et des Chrétiens de Villena. Ces anciennes célébrations véhiculent leurs propres valeurs et marques d'identité, lesquelles ont également servi à stimuler et diversifier l'économie locale. Par ailleurs, après avoir été officiellement déclarées en 2015 " attraction touristique nationale " par la campagne " 4 septembre, tous fous ", ces fêtes ont généré des défis, des incertitudes et des opportunités pour le développement touristique qui exigeront, pour que celui-ci réussisse, de découvrir les bonnes stratégies créatives et une gestion économique appropriée.
Ce document est protégé par la loi sur le droit d'auteur. L’utilisation des services d'Érudit (y compris la reproduction) est assujettie à sa politique d'utilisation que vous pouvez consulter en ligne.

https://apropos.erudit.org/fr/usagers/politique-dutilisation/ 


\title{
THE CULTURAL LEGACY OF THE FRONTIER LANDS OF Vinalopó (Alicante, Spain) AND THEIR tOURIST USE - IMPOSSIBLE MISSION?
}

\author{
Antonio Martínez Puche \\ University of Alicante \\ Salvador Martínez Puche \\ University of Murcia
}

\section{Cultural resourcse of Vinalopó - frontier land}

The land located in the northwestern area of the province of Alicante (Spain), which makes up the Vinalopó regions, has always been a frontier land $^{1}$. The High and Middle Vinalopó regions, made up of 21 municipalities, have common features but also other features which differentiate them. It is a land of castles, because of its defensive feature, and it is also varied in terms of languages as there are some municipalities which are only 5 $\mathrm{km}$ away and where Spanish or Valencian is spoken. It has been so since the $13^{\text {th }}$ century, when the frontiers between the kingdoms of Aragon and Castille were defined (Almizra Treaty in 1244). There are also some cultural practices, such as the Moors and Christians Festival, which recall the razzias among the Christian kingdoms and the Muslim taifas, from the $18^{\text {th }}$ century up to now. It was also a frontier during the Spanish Civil War, being the last bastion of the constitutional government of the $2^{\text {nd }}$ Republic. And nowadays, it is the administrative frontier with Murcia, Albacete and Valencia. All this has led to a (tangible or intangible) heritage and a cultural and landscape legacy, which is the base of an interior tourism offer, which complements the sun and beach. This scientific article goes through

1. $\mathrm{R}+\mathrm{D}+\mathrm{R}$ Competitive Project (CSO2013-41374-R) entitled "Restructure, conversion, revaluation, and reinvention of interior tourist spaces in Spain. Case study and strategies facing the crisis" (2013-2016). Ministry of Education, Culture and Sport. Coordinated by the Autonomous University of Barcelona (PhD. Gemma Canoves Valiente) 
some experiences, although it considers an element of remarkable tourist potential the declaration made in 2015 of Villena's Moors and Christians Festival as a Festival of National Tourist Interest, in order to declare this traditional festival a singular and experiential tourist product. We hereby specify the way the local population and the potential visitors have been informed and made aware of cultural heritage in a context of frontier land.

\section{The Moors and Christians Festival - footprint of a medieval past}

The historical footprint has also been noticed in landscapes and traditions, being these municipalities' economic, linguistic, defensive and cultural frontiers. The Moors and Christians Festival has a lot to do with this frontier feature, but above all the Tractat d'Almizra performance, which has been performed in one of the smallest towns in Vinalopó (Camp de Mirra) every year since 1976 by a part of the local population, who evoke the memory and the historic commemoration. The Moors and Christians Festival belongs to this context, as for over 200 years it has commemorated the frontier confrontation between both sides in the Reconquest. It was in the $16^{\text {th }}$ and the $17^{\text {th }}$ centuries that it was developed and it was in the $19^{\text {th }}$ century that this festival became popular in numerous towns in the different autonomous communities, especially in the province of Alicante. Regarding Villena, we should point out that in 2014 the festival was declared a National Tourist Interest (Official State Gazette, BOE no. 50 of $27^{\text {th }}$ February 2015)

The Moors and Christians Festival is a historic performance which commemorates the occupation of Granada by the Catholic monarchs in 1492, ending in this way the Muslim control of the Iberian Peninsula. Throughout the years, the popular plays which recalled that episode were becoming a cultural festival in many Spanish towns (Checa, 2000:16). Beyond their deontological and religious considerations, in their origin these festivals share symbols, texts, clothing, and staging, which were even exported to Hispanic American countries (Warman, 1985). There is no doubt we are facing what Baudrillard (1978) would describe as a bloodless and festive "simulation" between what is Christian and Muslim. However, it is also a conflict which confronts what is your own and what is someone else's, present and past, tradition and modernity, culture and tourism, reality and fiction.

History is re-enacted this way through a system of dramatized and idealized coding which reinterprets the events from the point of view of 
the Catholic paradigm of Trent in a baroque and absolutist Spain (Gómez, 2008:97 and others). It is a mythology which activates a festive time and space with ceremony uses which constitute the immaterial cultural heritages of different societies, as recognized by UNESCO in 2003.

Culture then becomes a resource, in the sense that it turns into a social occasion which fosters social and identity-related cohesion and it provides residents in a particular area with some value or interest which meets some of their needs (De la Calle, 2013:84). One example shows the need for humans to channel their festive character, the so-called homo festus (Gil Calvo, 1991). This is a feature which is also linked to the typical tourist in search of the extraordinary and a break from routine (Urry, 2004). We go from 'everyone's celebration' to 'a celebration for everyone' (Velasco et al, 1996) and we can add those visitors who consume the appealing elements which have been so strategically displayed for that purpose. The duality between 'Moor' and 'Christian', the exotic 'other' and 'us' is still valid, not only because it evokes the past but also as an updating process of the meanings attached to the modern tourist event advertised as such. That is why now 'our' festival turns out to be exotic for the 'other'. Tradition, transformed into consumable authenticity (MacCannell, 2003), works as a generating device and a product which encourages tourist demand, taking advantage of its intrinsic importance, its uniqueness and the festival's recreational character.

The festival ritual undergoes a touristification process through which its most dramatic sense prevails, which assigns archetypal, aesthetic and singular values in order to make it desirable (Donaire, 2012:212). Although it is a mechanism of festive sociability exclusive to the local direct participants, it is becoming festive sociability for the indirect participants or visitors, which implies inclusive tourism. In the experiential industry, consuming a tourist product plays an important part which influences decision making.

Besides being a great show in the street with peculiarities such as the participants' style, the forming of special squads or the numerous groups, the Moors and Christians Festival is a celebration which is rooted and which is lived intensely as an authentic vital, personal and collective experience. This feeling of belonging is seen in massive participation, ${ }^{2}$ shining with the authenticity and the sociocultural signs of identity, and strengthening the traditional values and the local resources (Image 1 and Image 2).

2. More than 14,000 people participate actively in the parades which are celebrated in Villena among the local participants, court, dancers and local music bands, etc. 


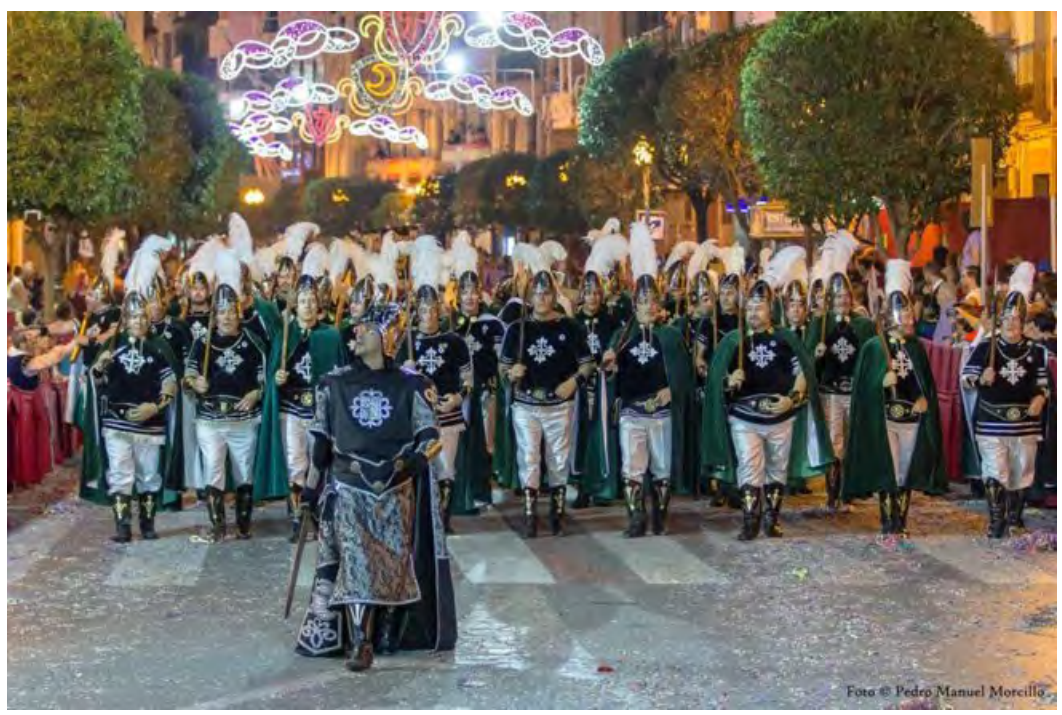

Image 1. Christians parade in Villena. Photo by P.M. Morcillo. El Mundo (2014)

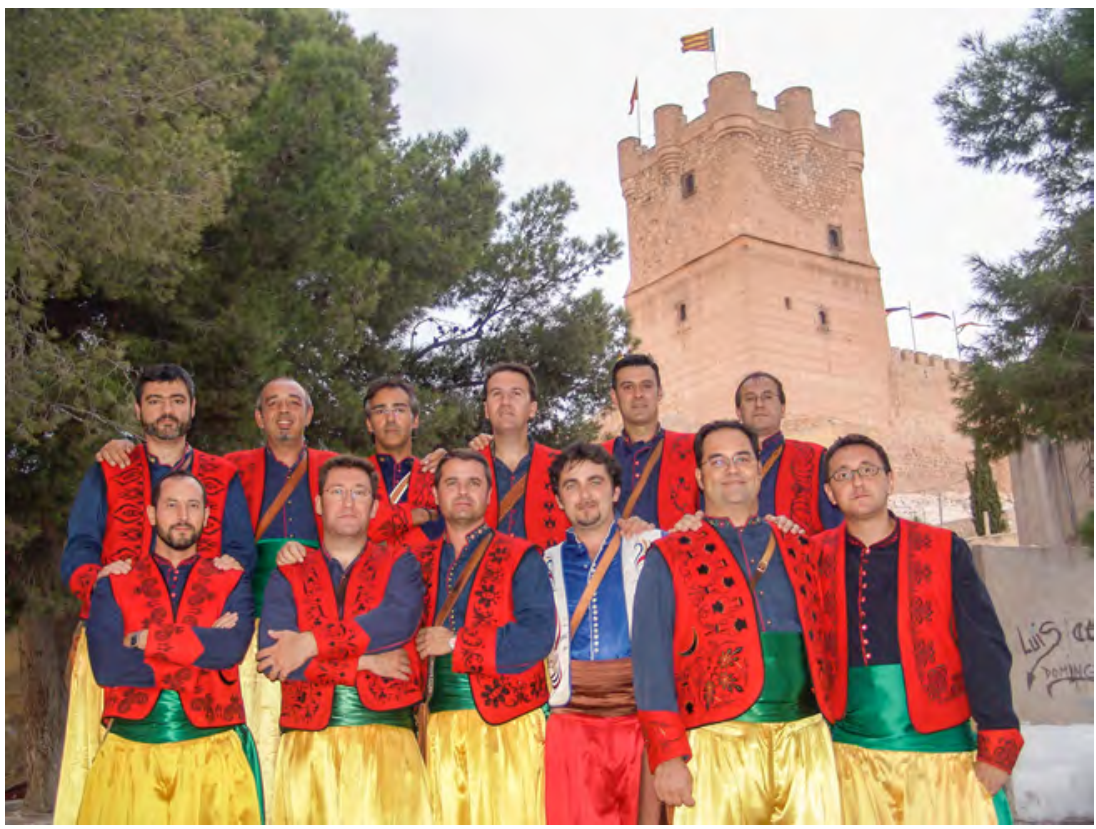

Image 2. Moors under the 14th century Castle in Villena. Photo by the authors 

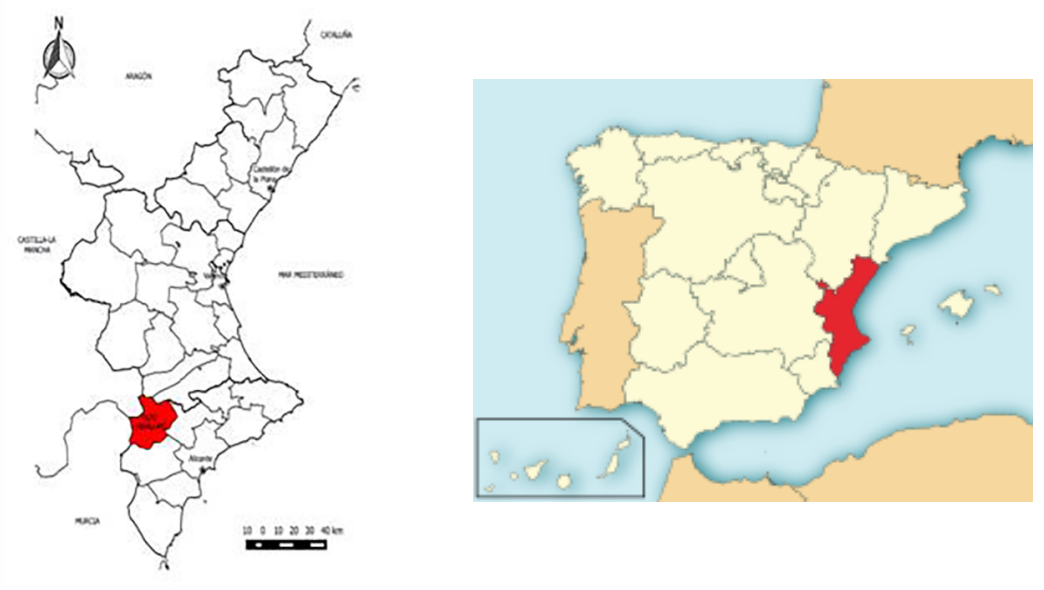

Map 1. Localisation map (Region of Valencia-Spain).

In the Vinalopó region, this festival is not only celebrated in Villena every year from September $5^{\text {th }}$ to $9^{\text {th }}$ (with its 14 troupes), but it is also celebrated in other towns such as Biar (from May $10^{\text {th }}$ to $13^{\text {th }}$, with seven troupes), Sax (from February $1^{\text {st }}$ to $5^{\text {th }}$, with four troupes, Beneixama (from September $6^{\text {th }}$ to $10^{\text {th }}$, with four troupes), Salinas (in May, with three troupes), and Campo de Mirra (from August 20th to $26^{\text {th }}$, with two troupes). Therefore, the Moors and Christians Festival is a tourist and cultural activity of great tradition in the region, which is greatly supported by public organizations and local associations, resulting in this festival's being well consolidated.

\section{Socioeconomic profitability and tourist assesment of the Moors And Christians Festival}

Popularity and identity still remain at the core of the celebrations but evolution and adaptation to the new ways of living have created a certain degree of standardisation, favouring economic interests, not only because around the festival there is a range of production and economic sectors, including tourism, but also because the participants' associations have taken on corporate structures and functionalities. 


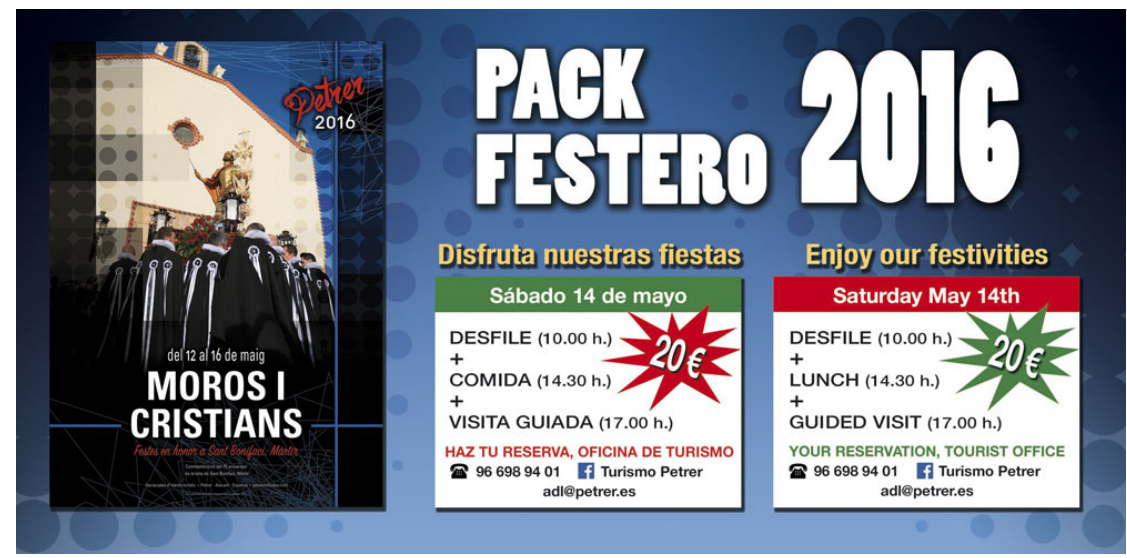

Image 5. Pack Festero in Petrer (Half Vinalopó). Created by Valle de Elda (April 2016).

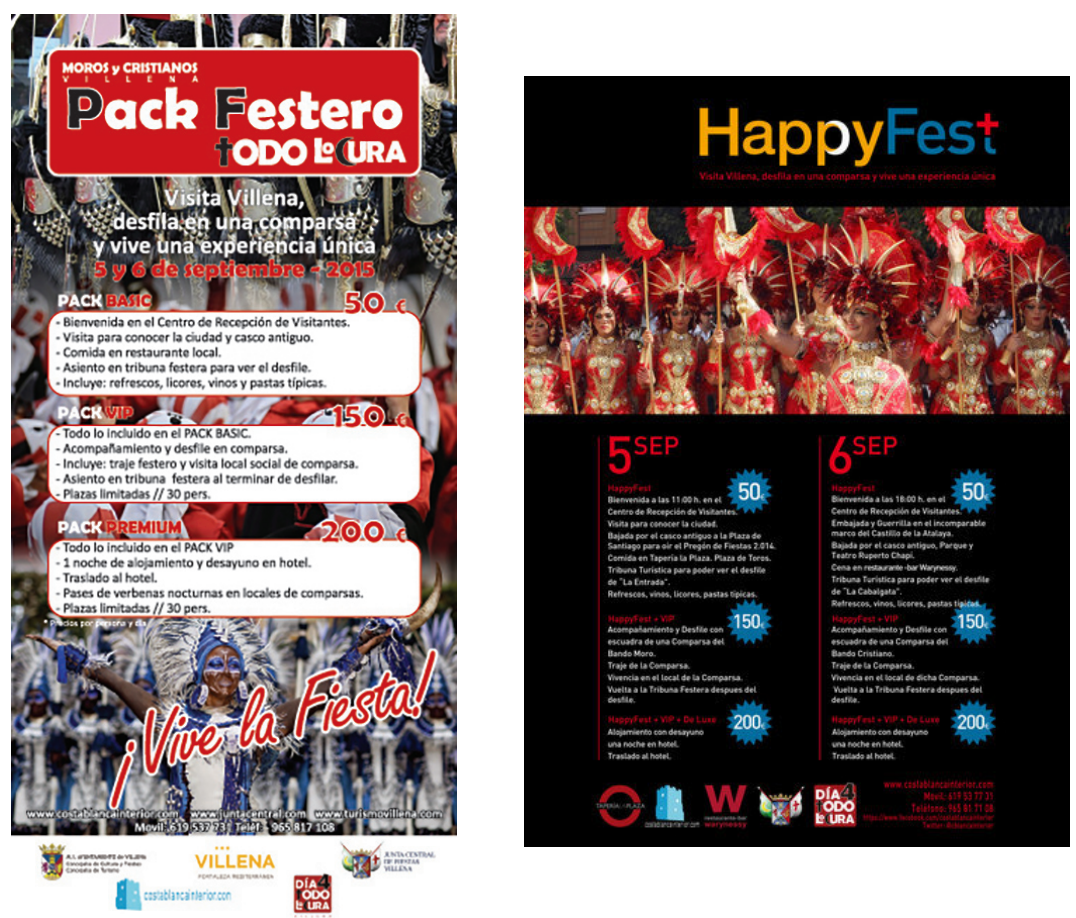

Image 6 and Image 7. Pack Festero in Villena (2015). "Villena visits, it parades in the Moors and Christians, and an unique experience lives." Created by Junta Central de Fiestas, town hall and Salvatur Travel 


\section{Villena, tourism capital of the High Vinalopó?}

The Territorial Strategy called Villena + Innovation, ${ }^{3}$ carried out and finished in March 2014 by the University of Alicante, suggested a new participative diagnosis through which a hundred students from the three secondary education centres from Villena highlighted the most remarkable resources in the town. In this qualitative analysis, the first six highlighted resources were, in order of preference: the Atalaya Castle (96.3\%), the Bullfighting Ring (80.4\%), the Historical Centre and monuments (64.5\%), others (cultural equipment and basic facilities such as museums, the cultural centre or the dumping site; some spaces, such as the Crosses and the Virgin; some aspects such as the relation with other towns in the region, etc.) (29.9\%), the Moors and Christians Festival (22.4\%), and Chapí Theatre $(18.7 \%)$. In fact, these elements were highlighted by the majority in the mind maps which the students drew in the different workshops (Image 8).

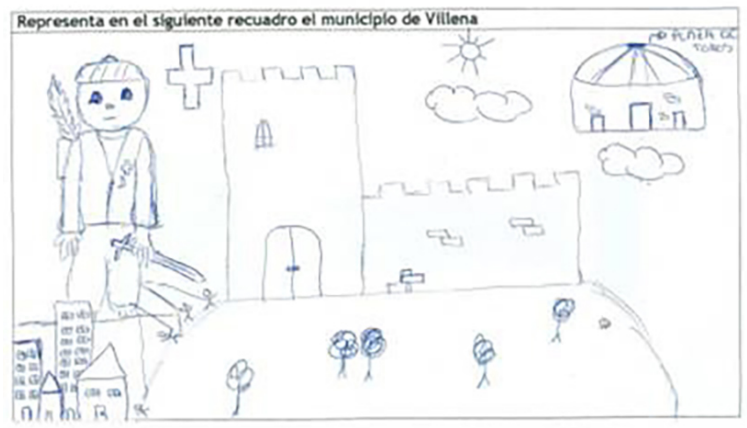

Image 8. Mind map of the students from Villena, highlighting the Festival and Heritage. Source: ETV+i. Alicante University

It must be pointed out that the activities performed to promote and adapt the resources have started to give some results. This way, in 2004 Villena received 60,674 visits, which meant $66 \%$ more than in 2013 . This dramatic growth is also due to the fact that the Atalaya Castle (the main tourist attraction) was closed for monument renovation, excavations, and refurbishment for a year and a half. However, there is no doubt that it was the resource that had the most visits that year, with a total of 21,778 people or $78 \%$ of them visitors participating in the guided tours offered by the Tourism Office and the Visitors Centre. This last facility, created in the PDPT framework (the plan to revitalize tourist products) is the

3 http://www.etvi.villena.es/ 
The expression "Día 4 que fuera y lo pasao, pasao" (I wish it were day 4, whatever happened) acts as the festival principle, being also the title of a pasodoble dance and the name of the official gazette of the festival's Central Board. The purpose of using this expression was to keep its meaning while making it more commercial and appropriate for its use as a motto. Therefore, "Día 4 Todo (lo)cura" has a double meaning (Day 4 is crazy or Day 4 cures everything):

a) It expresses the longing, desire and yearning with which people look forward to the festival, which begins on September $4^{\text {th }}$ as a way of breaking the routine and intensely enjoying oneself throughout the five days. The pre-festival ceremonies change people's mood, while everything gets crazy.

b) It expresses the philosophy through which the festival is understood and lived. People's worries and problems are put away until after the festival. This break cures everything, or at least postpones it.

In the first edition, 20 kits were made. Due to its strictly promotional and not commercial nature, 3 local companies participated free of charge: Ricardo Menor Winery, La Francesa Bakery and the transportation company Tips@. In the year 2015, 300 more kits were made, having the following distribution and use: 200 to be sold at 25; and 100 for institutional protocol, from which 60 were sent to bloggers, means of communications and tourist organizations, 20 were kept as gifts and 20 were taken to Fitur 2016.

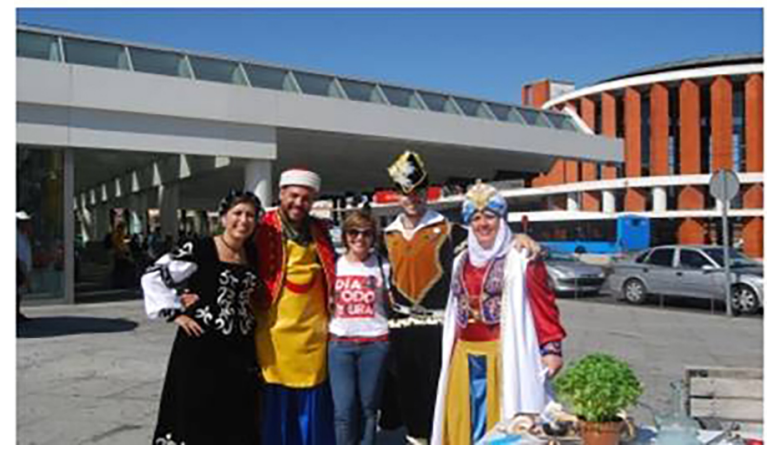

Image 9. Moors and Christians outfits at Atocha Railway Station in Madrid. Source: Villena Town Hall. 
Following is a localisation map of this festival in the region (Map 2) and a descriptive table with the tourist information points in the region and the institutions and organizations which are directly related to this product.

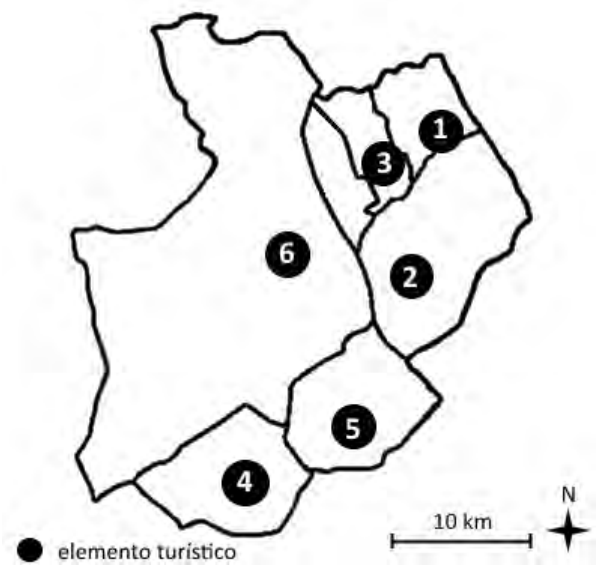

Map 2. Geographic localisation of the Moors and Christians Festival in the region Haut Vinalopó.

\begin{tabular}{|c|c|c|}
\hline No & Tourist element & Town \\
\hline 1 & Moors and Christians Festival from Beneixama & Beneixama \\
\hline 2 & Moors and Christians Festival from Biar & Biar \\
\hline 3 & Moors and Christians Festival from Campo de Mirra & Campo de Mirra \\
\hline 4 & Moors and Christians Festival from Salinas & Salinas \\
\hline 5 & Moors and Christians Festival from Sax & Sax \\
\hline 6 & Moors and Christians Festival from Villena & Villena \\
\hline
\end{tabular}

In 2015 the Moors and Christians Festival was held in 6 towns in the region, whose registered population has decreased $1.92 \%$ in the last five years, while the total population has decreased $1.84 \%$ (according to the provincial government of Alicante, 2015).

In the region there are 19 local agents directly related to this tourist product, although 74 companies also provide economic and/or social support to this festival. Regarding tourist accommodation in all the towns in the region where this type of tourism is offered, in 2015 for every 1,000 tourists there was an availability of 10 hotel vacancies and other rural housing vacancies, and no camping vacancies (provincial government of 
Alicante, 2015; Valencian Building Institute, 2015). Additionally, there are 20 regional websites on the Internet (digital magazines, town halls, tourism portals) where this product is promoted.

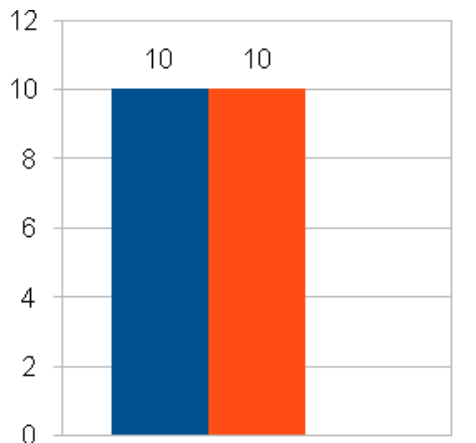

Vacancies in the hospitality establishments in

- the towns of the region in which this tourist product is offered per 1,000 tourists.

Vacancies in the rural hospitality establishments - in the towns of the region in which this tourist product is offered per 1,000 tourists.

Vacancies in the campsites in the towns of the region in which this tourist product is offered per 1,000 tourists.

Image 4. Vacancies in the tourist establishments in the cluster for every 1,000 tourists. Own source from the data provided by the provincial government of Alicante (2015) and the Valencia Building Institute (2015)

In relation to the flow indicators, the tourist population in these towns has decreased $1.65 \%$ from 2010 to 2014, although they are only $27.67 \%$ of the total population there. Besides, the festival is an event which creates a great number of visits, as it is celebrated only once a year.

Regarding the socio-cultural aspects, the tourist population is quite inferior to the registered population, with a difference of $0.38 \%$ Likewise, the existence of second homes in such towns is also very low, being $0.24 \%$ of the relation between them and first homes. This is the reason why the impact in this area is low. However, the degree of the tourists' satisfaction with their experience when consuming this product is high, as the average assessment is 4 out of 5 .

In relation to the environmental impact, all the towns have a development strategy for sustainable tourism, correct access and enough parking spaces available.

Therefore, we are facing a cluster formed around the Moors and Christians Festival, which is in a very developed stage and which has a consolidated relation among the agents related to this product (public organizations, local associations, business organizations, research institutions, hotels, restaurants, shops, and local companies). Its sociocultural sustainability is high, as well as its environmental one. Nevertheless, as we are dealing with a seasonal event, its economic sustainability is a little more fragile, as its budget balance highly depends on public and private economic support. 


\begin{tabular}{|c|c|}
\hline $\begin{array}{l}\text { Tourist Information Offices and } \\
\text { tourist interpretation centres in the } \\
\text { region }\end{array}$ & Public agents \\
\hline Villena Visitor Centre & Villena Town Hall \\
\hline \multirow[t]{5}{*}{ Biar Tourism Office } & Sax Town Hall \\
\hline & Beneixama Town Hall \\
\hline & Biar Town Hall \\
\hline & Campo de Mirra Town Hall \\
\hline & Salinas Town Hall \\
\hline Local associations & Business organisations \\
\hline \multirow{2}{*}{$\begin{array}{l}\text { Villena Central Board of the Moors } \\
\text { and Christians Festival }\end{array}$} & Agribusiness Association of Villena \\
\hline & Business and Entrepreneurs \\
\hline $\begin{array}{l}\text { El Rabal Residents' Association } \\
\text { (Villena) }\end{array}$ & Association of Biar \\
\hline Beneixama UEFMYC & $\begin{array}{c}\text { Hotel Management and Tourism } \\
\text { Association of Biar }\end{array}$ \\
\hline Biar Musical Association & \\
\hline \multicolumn{2}{|l|}{$\begin{array}{l}\text { Pobla del Duc Musical Association } \\
\text { (Biar) }\end{array}$} \\
\hline $\begin{array}{c}\text { Musical Association La Pau } \\
\text { (Beneixama) }\end{array}$ & Research institutions \\
\hline \multicolumn{2}{|l|}{ Residents' Association Salinas } \\
\hline $\begin{array}{c}\text { Sax Artistic and Musical Association } \\
\text { El Rabalillo Association (Villena) }\end{array}$ & Alicante University \\
\hline
\end{tabular}

Table 1. Tourist information points in the region and institutions and organizations which are more directly related to this cluster. Source: Created by authors

At a time when tourist destinations must compete, offering its visitors attractions which should stand out in a particular way, the Moors and Christians Festival can find its opportunity in the context of a cultural and creative kind of tourism. Creative tourism, funded by Professor Greg Richards, from Tilburg University (Holland), aims to study the evolution of this trend, which is related to experience, with a particular place and 
its people, where the Moors and Christians Festival could serve as a bestpractice example, in a way, if cultural products for tourists were created with a view to making the visitor notice from within the atmosphere, the feelings when they are parading, the music, the gunpowder (harquebus shots in guerrilla re-enactments), gastronomy, culture and history of the place they are visiting. They would be sharing this experience with those who take part actively in the festival (musicians and participants). Cultural tourism has arguably been one of the major growth markets in global tourism in recent decades (Richards, 2012). The growing desire for cultural experiences on holiday has been driven by rising education levels, the subsequent growth of cultural capital and simply by the expansion of tourism itself, which has brought larger numbers of people into contact with other cultures. The idea that Bohemian cool is becoming a major driver for urban economies echoes Florida's (2003) ideas that creativity is an essential asset for contemporary cities, but also creativity is seen as one potential solution to problems of commodification and serial reproduction, both of which seem particularly prevalent in cities. Creativity has therefore been used in a number of ways in tourism, including tourism products and experiences, valorising cultural and creative assets and creating buzz and atmosphere. The growing demand for this kind of experience is linked to a consumer's need to define their own identity using the product they are consuming, willing to express themselves and get in touch with others, even though they are far away. Holidays are no longer a break to rest, but they have become the opportunity for learning and for personal growth, and also the time when learning occurs through experience. Among the movements that have emerged around this type of travelling experience we can see 'meet the locals' or 'like a local' and, as expected, the Internet and social networking sites are the ideal places to get information (http://www. costablancainterior.com/package/happyfest/). The range of products grows day by day, with alternatives that go from a short visit of a few hours to trips that last for a few weeks. If we do not want to get lost in the confusion that the Internet may cause, there are platforms like Creative Tourism Network, created in Barcelona in 2010, which put visitors in touch with those who offer a particular experience. Can this be done in the Moors and Christians Festival? We believe so, as there are companies in some towns in the Vinalopó area which are trying to turn the festival into a business as a tourist experience (Images 5, 6 and 7). 


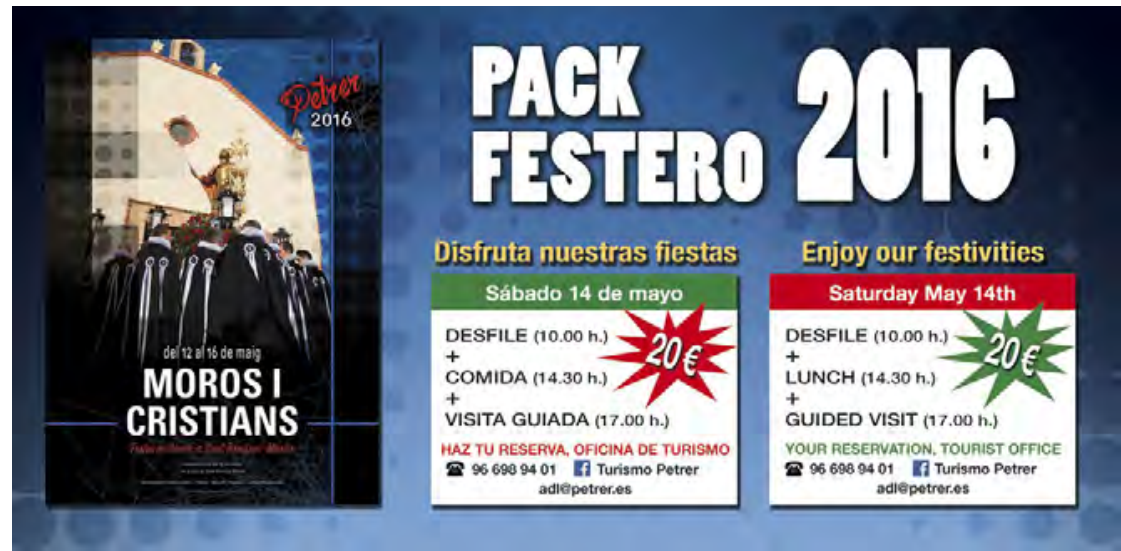

Image 5. Pack Festero in Petrer (Half Vinalopó). Created by Valle de Elda (April 2016).

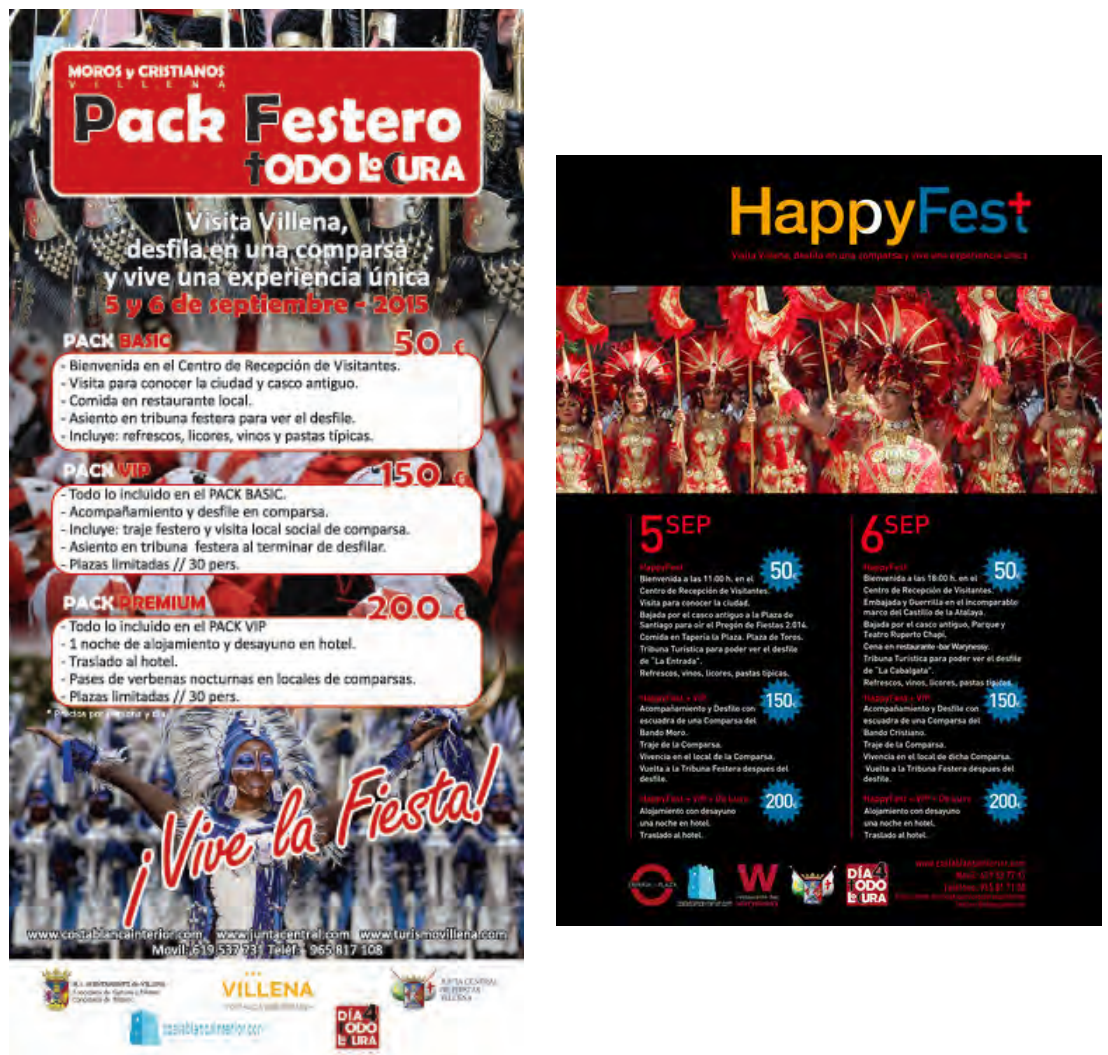

Image 6 and Image 7. Pack Festero in Villena (2015). "Villena visits, it parades in the Moors and Christians, and an unique experience lives." Created by Junta Central de Fiestas, town hall and Salvatur Travel 


\section{Villena, tourism capital of the High Vinalopó?}

The Territorial Strategy called Villena + Innovation, ${ }^{3}$ carried out and finished in March 2014 by the University of Alicante, suggested a new participative diagnosis through which a hundred students from the three secondary education centres from Villena highlighted the most remarkable resources in the town. In this qualitative analysis, the first six highlighted resources were, in order of preference: the Atalaya Castle (96.3\%), the Bullfighting Ring (80.4\%), the Historical Centre and monuments (64.5\%), others (cultural equipment and basic facilities such as museums, the cultural centre or the dumping site; some spaces, such as the Crosses and the Virgin; some aspects such as the relation with other towns in the region, etc.) (29.9\%), the Moors and Christians Festival (22.4\%), and Chapí Theatre (18.7\%). In fact, these elements were highlighted by the majority in the mind maps which the students drew in the different workshops (Image 8).

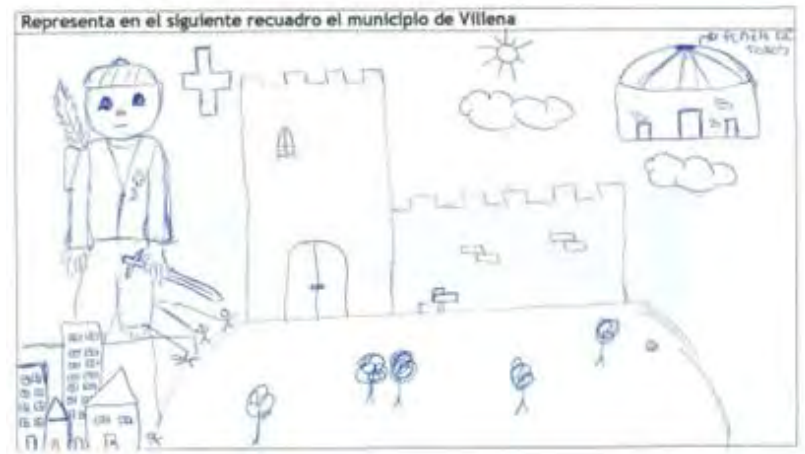

Image 8. Mind map of the students from Villena, highlighting the Festival and Heritage. Source: ETV+i. Alicante University

It must be pointed out that the activities performed to promote and adapt the resources have started to give some results. This way, in 2004 Villena received 60,674 visits, which meant $66 \%$ more than in 2013 . This dramatic growth is also due to the fact that the Atalaya Castle (the main tourist attraction) was closed for monument renovation, excavations, and refurbishment for a year and a half. However, there is no doubt that it was the resource that had the most visits that year, with a total of 21,778 people or $78 \%$ of them visitors participating in the guided tours offered by the Tourism Office and the Visitors Centre. This last facility, created in the PDPT framework (the plan to revitalize tourist products) is the

3 http://www.etvi.villena.es/ 
second most visited place with a total of 13,024 visits a year ( $21 \%$ of total visits), which means an average of 1,085 visitors a month. With a total of 11,492 visits (19\%), the third most visited resource was the José María Soler Archaeological Museum, which is home to the well-known Treasure of Villena. Completing the cultural package, and in the fourth position in the visits registry, is the Arciprestal Church of Santiago, with 3,145 visits. Regarding seasonality, April was the month with the most visits (14.4\%) due to the Holy Week celebrations, followed by August (with 11\%) and May (with $10.2 \%$ ). Of all the visits, $84 \%$ were domestic excursionists while $16 \%$ were foreigners. It must be pointed out that, compared to 2013, when 91\% of the visitors were Spanish visitors and only 9\% foreigners, there has been a significant increase. Besides the tourists from the coast, there is also a considerable increase of travel agencies throughout 2014, with a total of 25 ( 15 being Spanish and 10 foreign). In relation to previous years, it must be highlighted that there has been an outstanding increase, as 16 travel agencies came in 2013 and only 9 in 2012.

Also during 2015, the authorities applied for the centenary Moors and Christians Festival to become a National Tourist Interest Festival, as the Secretary of State for Tourism had made known the need to meet the requirements, increasing the number of advertising or promotional news entries issued in the national means of communication (press, radio, and television).

From that moment on, a campaign with the following objectives was created:

a) External: obtaining national media presence; to project an attractive image, getting a differentiating positioning of the Moors and Christians Festival from Villena; establishing and consolidating a product which completes the cultural and tourist offer from the town.

b) Internal: getting the direct and indirect participants involved in the promotion; promoting merchandising which contributes to spreading the festival, counting on the active participation of the local residents; facilitating self-financing of the campaign.

This advertising campaign was developed during the summer of 2014 (from June to September) and it consisted of the following strategies:

The night Moors and Christians parade (La Cabalgata) applied for the Guiness World Record as the most participatory one in the world. In the end, the record was obtained but in the category of "dancing with swords," a more generic modality which does not exist anymore. 
A festival kit was prepared and sent to 20 national communication media (press, radio, television, and cultural and tourist magazines). Several elements which are related to the festival are included in a shoe box (local production sector), which is designed as a first aid kit in which a red cross wraps each box as a lace. The box is made up of: basil, local pastries, liqueurs (katakí, anisette, and French lavender), confetti and streamer, badges from the troupes, a fez, and a USB with photo, videos, music and recorded speech in order to bring the senses into play. Besides, there is an instruction manual which explains each and every step to be followed to enjoy each kit element to the maximum (image 10). The box claims to recall the experiential character.

AVE (high speed train) Atocha Railway Station. On August 28 $8^{\text {th }}$ ,2014, four festival representatives (among whom were the president of the Royal Moors and the president and vice-president of the corporals), who were wearing their troupe outfits, went to Madrid by train from AVE Villena railway station. During the journey, they interacted with the train passengers, taking photographs and videos, which were later shared in the social networks with the tag \#dia4todolocura and \#fiestasderecord ${ }^{4}$ (images 9 and 10).

Therefore, the core of the advertising campaign, "Día 4 todo locura" (Day 4 is crazy) focused on three elements and distinguishing of the Moors and Christians Festival with relation to other festivals which share the same basis and origin in the Levante region:

a) Apart from being a grand street show with peculiarities such as the corporals' styles, the making of special squads or the numerous groups, it is one of the most established celebrations which people live intensely as an authentic vital experience.

b) This feeling of belonging is shown in the massive participation, which is the highest in all the Spanish towns where the Moors and Christians Festival is celebrated. More than 14.000 people participate actively in the parades: local festival participants, courts, dancers, local music bands, etc.

c) The advertising campaign must preserve the authenticity and the sociocultural signs of identity, strengthening traditional values and local resources.

4. http://www.elperiodic.com/villena/noticias/321626_fiestas-record-moroscristianos-villena-llegado-madrid.html

5. The motto is also made up of 14 characters (among letters and numbers) which refer to the 14 troupes, 7 Moor troupes and 7 Christian ones. Additionally, it is possible to introduce graphic symbols representing the Moor half-moon in the letter " $\mathrm{C}$ " and the Christian cross in the "T". 
The expression "Día 4 que fuera y lo pasao, pasao" (I wish it were day 4, whatever happened) acts as the festival principle, being also the title of a pasodoble dance and the name of the official gazette of the festival's Central Board. The purpose of using this expression was to keep its meaning while making it more commercial and appropriate for its use as a motto. Therefore, "Día 4 Todo (lo)cura" has a double meaning (Day 4 is crazy or Day 4 cures everything):

a) It expresses the longing, desire and yearning with which people look forward to the festival, which begins on September $4^{\text {th }}$ as a way of breaking the routine and intensely enjoying oneself throughout the five days. The pre-festival ceremonies change people's mood, while everything gets crazy.

b) It expresses the philosophy through which the festival is understood and lived. People's worries and problems are put away until after the festival. This break cures everything, or at least postpones it.

In the first edition, 20 kits were made. Due to its strictly promotional and not commercial nature, 3 local companies participated free of charge: Ricardo Menor Winery, La Francesa Bakery and the transportation company Tips@. In the year 2015, 300 more kits were made, having the following distribution and use: 200 to be sold at 25; and 100 for institutional protocol, from which 60 were sent to bloggers, means of communications and tourist organizations, 20 were kept as gifts and 20 were taken to Fitur 2016.

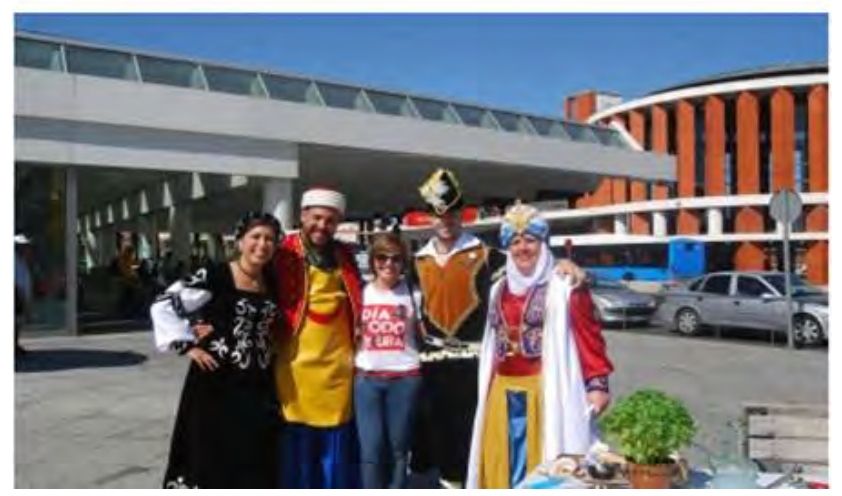

Image 9. Moors and Christians outfits at Atocha Railway Station in Madrid. Source: Villena Town Hall. 


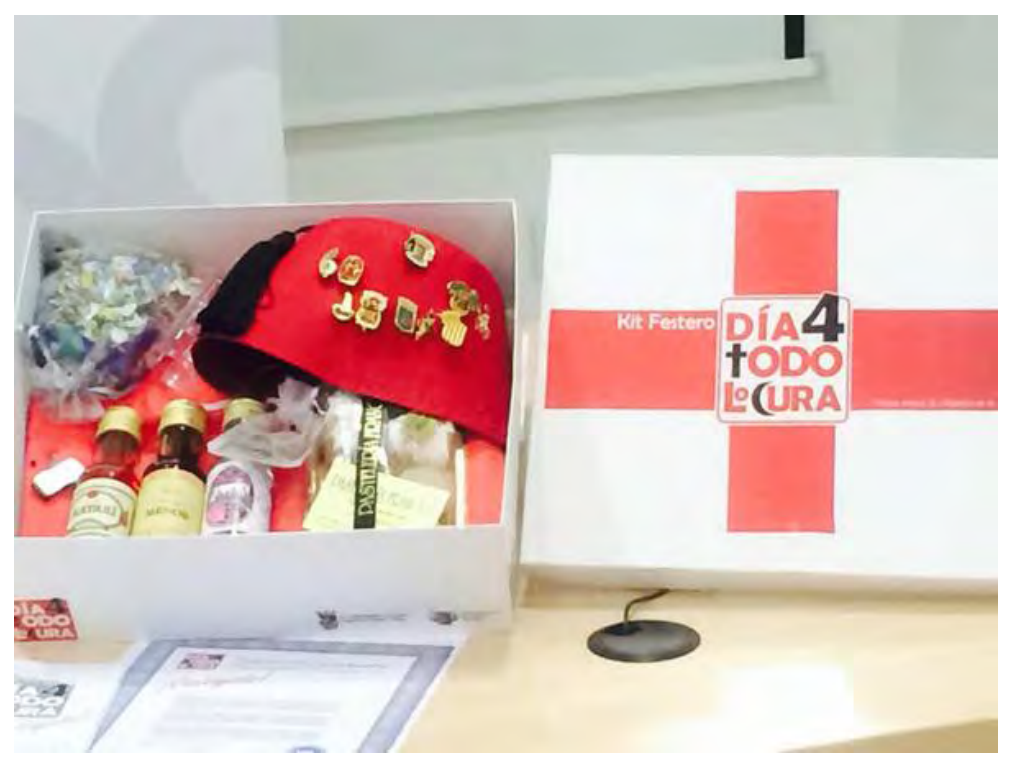

Image 10. Villena Festival Kit from the campaign "Día 4 todo locura." Source: Newspaper, Portada.info

\section{Conclusions}

The region of High Vinalopó (Alicante) is a frontier land culturally rich and heterogeneous. It is located in the northwest of the county of Alicante. It owes its name to the fact that geographically it is in the high part of the valley of Vinalopó. Their capital is the city of Villena. It has a surface of $674 \mathrm{~km} 2$ and in the year 2015 it had a population of 54,061 inhabitants. The district bases its economy on the textile industry and on footwear, among others, and in smaller measure on agriculture and services.

This has led to a particular idiosyncrasy in the area, where languages spoken, traditions, landscapes and cultural heritage make it a special land. Among the cultural heritage assets we should point out the Moors and Christians Festival, which were considered a National Tourist Interest in 2014. All this makes the possibility of managing, from the tourist point of view, a tradition which is historic, cultural, popular and bicentenary in this land. In turn, the role of "communion" is reclaimed, much more than the role of division, which is implied in the concept of frontier as integrated and integrating perception, vision, and mission. About this, Azorín, the writer from Alicante, stated in his work "the real Alicante, the genuine one, is not the one with a frontier with Murcia, neither the one near 
Valencia, it is the high area, the hilly one, the one that is made up of the towns of Villena, Biar, Petrel, Monóvar, and Pinoso". ${ }^{6}$ We consider it a need to amplify the application of the concept of frontier to the regional and provincial lands as nowadays it is being tried from the tourist point of view, through the "Castles routes" and the "Alicante Wine Routes," with very varied results, not being very inclusive occasionally. In this sense, we should mention the project "Count Lucanor Route" (project granted by the Ministry in 2014), ${ }^{7}$ in which the town of Villena (in Alicante), Escalona (in Toledo) and Peñafiel (in Valladolid) participate. This route is trying to put together a tourist and cultural offer taking as a starting point the old territory of the Villena Manor and in particular, the territory held by D. Juan Manuel, the Prince of Villena ( $14^{\text {th }}$ century). Finally, it must be pointed out that we should measure, quantify and qualify the socioeconomic and cultural effects of touristifying a popular festival (tourist experience and life), which has also set up an economic alternative derived from the shoe and textile cluster (economic frontier of the towns in Vinalopó and Alocià regions), which can also be used as place branding. All this has contributed to the advertising and communication campaign entitled "Día 4, todo locura". Doubtlessly, the product we have proposed must involve the seven elements of tourism and local development: educating, experimenting and stimulating, looking for a remarkable balance between ethnography, economy and ecology or environment.

6. Azorín., Confesiones de un pequeño filósofo, 1987, Espasa-Calpe, Madrid, p. 37

7. Creative Techniques Workshop S.L.U. "Cultural Route of Count Lucanor. The Principality between Villena, Escalona and Peñafiel”, Record number: 78/179, of 7 th November 2014. Assistance to private companies in order to run projects of value, broadcasting and protection of cultural heritage assets. Ministry of Education, Culture and Sport. 


\section{References}

Baudrillard, Jean. 1978. Cultura y simulacro. Madrid: Kairós. 1998 (5aㅡ ed.) De la Calle Vaquero, Manuel. 2013. "Los recursos del turismo cultural." In Pulido Fernández et al. (eds.), Turismo Cultural :81-116. Madrid: Síntesis.

Donaire, Jose Antonio. 2012. Turismo cultural. Entre la experiencia y el ritual, Bellcaire d'Empordá: Edicions Vitel.la

Florida, Richard. 2003. "Cities and the Creative Class." City \& Community 2(1): 3-19.

García Pilán, P. (2006): "Sociabilidad festera: retradicionalización selectiva y producción de sacralidades en la modernidad avanzada." Anduli: Revista Andaluza de Ciencias Sociales 6: 77-91.

Gil Calvo, E. (1991): Estado de fiesta. Feria, foro, corte y circo. Madrid: Espasa Calpe.

Gómez García, Pedro. 2008. "Religión y política desde las fiestas de moros y cristianos de la Andalucía barroca." In Actas del congreso internacional Andalucía Barroca. IV. Ciencia, filosofía y religiosidad: 97-103. Sevilla: Consejería de Cultura de la Junta de Andalucía.

MacCannell, Dean. 2003. El turista. Una nueva teoría de la clase ociosa. Barcelona: Melusina

Martinez-Puche, Antonio. 2013. "Turismo de interior, identidad y cultura glocal. Valoraciones y propuesta." In Francisco Javier Melgosa Arcos (eds.), Turismos de interior: 43-77. Madrid: Síntesis.

Martínez-Puche, Antonio. 2014. "La ruta del vino en la provincia de Alicante ¿Oportunidad u oportunismo?.” In Francisco López Palomeque and Gemma Cánoves Valiente (eds.), Turismo y Territorio. Innovación, renovación y desafíos: 503-513. Barcelona: Tirant Humanidades.

Martínez Puche, Antonio, Salvador Martínez-Puche and Francisco Morales Yago. 2016. "Turismo "de frontera" en las tierras del Vinalopó (Alicante). Crisol de identidades, cultura, economías, paisajes e historia, como base de la oferta turística." In Desarrollo local en territorios de frontera: 145158. Huelva, Servicio de publicaciones de la Universidad de Huelva. Martínez Puche, Salvador and Antonio Martínez Puche. 2016. "Representación, recurso, atractivo y rito: Día 4 todo locura o la promoción de las Fiestas de Moros y Cristianos de Villena." In Libro actas I Congreso Internacional sobre Fiestas de Moros y Cristianos. Alicante 2016. In press.

Morazzoni, Monica. 2003. Turismo, territorio e cultura. Milan: Instituto Geográfico De Agostini.

Richards, Greg and Julie Wilson. 2006. "Developing creativity in tourist 
experiences: A solution to the serial reproduction of culture?" Tourism Management 27: 1209-1223.

Richards, Greg. 2012. "Events and the Means of Attention." Paper presented at the ATLAS, Annual Conference, London, September, https://www. academia.edu/1955752/Events_and_the_means_of_attention

Saidi, Habib. 2010. "From Tourism Culture to Heritage Tourism." Ethnologies 32: 15- 22.

Urry, John. 2004. La mirada del turista. Lima: Universidad de San Martín de Porres.

Velasco, H.H. et al. 1996. "Fiestas de todos, fiestas para todos." Antropología 11: 147-167.

Velasco, M. (2009): "Gestión turística del patrimonio cultural: enfoques para un desarrollo sostenible del turismo cultural." Cuadernos de Turismo 23: 237-235.

Warde, Alan. 1997. Consumption, Food and Taste, Sage, London.

Ybarra, Josep Antoni. 1991. "Formaciones económicas en contextos de cambio: Distritos industriales en España. El caso del País Valenciano," Revista de Estudios Regionales 30: 57-80.

Zarate, Martin Antonio. 2010. "La visita de empresa en España, una modalidad turística en expansión”. In Libro de actas del 2ํㅡㄹ Congreso Europeo de Turismo industrial, Toledo 2008: 52-66. 